\title{
Model Perlindungan Hutan dengan Pendekatan Pemanfaatan HHBK bagi Masyarakat Kawasan Hutan Pendidikan UM Palangkaraya
}

\section{Forest Protection Model by NTFP Utilization for Forest Community in UMP's University Forest}

\author{
Siti Maimunah, S.Hut., M.P. \\ Unit Teknis KHDTK Universitas Muhammadiyah Palangkaraya \\ sitimararil@gmail.com
}

\begin{abstract}
UMP's University forest 4.910ha with lowland type and peat swamp forest types habitat have many potential of forest products specially non timber forest product (NTFP) like latex, resin, honey, tradisional medicine and ornamental plant near animal hunting (for stoping program). NTFP is one of opportunity of community to rising of economical values to make a management model for conservation base on community with more participating to protect the forest.

The research method is a NTFP inventory for 2 forest habitats to searching the market opportunity and community focus group discussion (FGD) to combine the data and community assumption.

The result of this research Is we can found a effective model of forest protection with economical community participated in our forest for NTFP. NTFP potential in UMP's University Forest are damar batu (resin), kopal damar (resin), latex of jelutung, rattan and tradicional medicine. We need more fasitating program and sosialisation activities for community for other NTFP in UMP's University Forest. The most product of 2015-2016 is resin of Shorea collection by community with average $50 \mathrm{~kg} / \mathrm{day} /$ collector and average of community income Rp. 125.000,00/day/collector.
\end{abstract}

Keywords : Protection Forest Model, NTFP, University Forest.

Intisari

Hutan Pendidikan UM Palangkaraya seluas 4.910 Ha bertipe habitat hutan dataran rendah dan hutan rawa gambut mempunyai potensi hasil hutan sangat beragam khususnya untuk hasil hutan bukan kayu (HHBK) meliputi produk damar, getah, madu, obat tradisional dan tanaman hias disamping hewan perburuan yang akan dibatasi. HHBK merupakan harapan baru bagi masyarakat sekitar kawasan hutan untuk peningkatan taraf hidup dan kesejahteraan sebagai model untuk perlindungan hutan yang ditawarkan oleh pengelola Hutan Pendidikan dalam rangka pelibatan masyarakat sekitar kawasan hutan, sehingga merasa turut memiliki hutan tersebut dan bersedia melindungi hutan karena manfaatnya dirasakan secara langsung.

Metode yang digunakan dalam penelitian ini adalah pendataan beberapa potensi HHBK yang berpeluang ekonomi dan peluang pasar untuk menopang kehidupan masyarakat sekitar kawasan hutan pendidikan dengan sistem Focus Group Discusion (FGD) dan data di lapangan untuk potensi HHBK untuk setiap tipe habitat.

Hasil diperoleh bahwa model perlindungan hutan yang efektif diterapkan di hutan pendidikan adalah dengan melibatkan masyarakat kawasan hutan dalam kegiatan peningkatan kehidupan sosial dan ekonomi. Dari kegiatan yang dilaksanakan, masyarakat belum optimal memanfaatkan hutan selain kayu dan cenderung melakukan penebangan liar hanya untuk membuat ladang berpindah. Informasi pengembangan HHBK di kawasan belum banyak diketahui masyarakat karena tidak adanya informasi pasar beberapa produk HHBK potensial kawasan Hutan Pendidikan. Produk HHBK unggulan kawasan tersebut antara lain damar batu, kopal damar,getah jelutung, rotan dan tumbuhan obat tradisional. Perlu adanya pendampingan dan sosialisasi guna peningkatan keterlibatan masyarakat dalam pemanfaatan HHBK di kawasan tersebut. Produk unggulan tahun 2015-2016 adalah damar batu dengan hasil $50 \mathrm{~kg} / \mathrm{har} /$ pengumpul dengan penghasilan rata-rata masyarakat pengumpul damar Rp. 125.000,00/hari/pengumpul damar. 


\section{Kata Kunci :Model perlindungan hutan, HHBK, Hutan pendidikan}

\section{Latar Belakang}

Upaya melestarikan hutan dilakukan dengan berbagai cara untuk menggugah kesadaran masyarakat akan pentingnya hutan bagi kehidupan. Hutan akan terancam rusak jika masyarakat yang hidup di sekitar hutan belum sejahtera dan dalam kondisi terpaksa merusak hutan untuk memenuhi kebutuhan dasar mereka.

Hutan adalah suatu lapangan bertumbuhan pohon-pohon yang secara keseluruhan merupakan persekutuan hidup alam hayati beserta alam lingkungannya dan yang ditetapkan pemerintah sebagai hutan. Jika pengertian hutan ditinjau dari sudut pandang sumberdaya ekonomi terdapat sekaligus tiga sumberdaya ekonomi (Wirakusumah, 2003dalam Syamsu Alam, dkk, 2009), yaitu: lahan, vegetasi bersama semua komponen hayatinya serta lingkungan itu sendiri sebagai sumberdaya ekonomi yang pada akhir-akhir ini tidak dapat diabaikan.

Di kehidupan masyarakat pedalaman Kalimantan, kehidupan masih bergantung pada alam. Dari alam masyarakat akan hidup dengan melakukan aktivitas mengambil dari alam dan bergantung pada alam baik dengan berburu, bertani secara tradisional ataupun mencari ikan di sungai. Masyarakat di Kalimantan belum merasakan betapa sulitnya seperti mencari ikan di sungai karena masih melimpah ketersediaannya di alam, mereka belum merasakan sulitnay mencari ikan di sungai yang ada di pulau Jawa. Kehidupan yang terlalu dimanjakan oleh alam ini menyebabkan masyarakat tidak semangat untuk mencari nafkah dengan cara yang susah. Hal ini menjadi masalah yang harus dicarikan jalan keluar untuk mencari model pengelolaan dan perlindungan hutan khususnya hutan pendidikan dengan pemanfaatan produk hasil hutan bukan kayu (HHBK) nya.

HHBK adalah produk sampingan hutan selain kayu yang mempunyai nilai ekonomi tinggi yang didefinisikan oleh FAO sebagai produk biologi asli selain kayu yang diambil dari hutan, lahan perkayuan dan pohon-pohon yang berada di luar hutan (Baharudin dan Taskirawati, 2009). HHBK merupakan sumber daya alam yang sangat melimpah di Indonesia dan memiliki prospek yang sangat baik untuk di kembangkan.

Hutan pendidikan merupakan kawasan hutan yang ditetapkan oleh Menteri Kehutanan sebagai suatu Kawasan Hutan Dengan Tujuan Khusus (KHDTK) sebagai kawasan untuk pembelajaran, kaji terap dan penelitian bagi dunia pendidikan 
(Anonim, 2014). Hutan Pendidikan UM Palangkaraya yang ditetapkan dengan SK Menteri Kehutanan RI No. 611/Menhut II/2014 pada Juli 014 merupakan suatu kawasan hutan produksi yang ditunjuk sebagai kawasan hutan dengan tujuan khusus sebagai hutan pendidikan Kota Palangka Raya eluas $4.910 \mathrm{Ha}$ juga mempunyai potensi HHBK yang sangat luar biasa jenisnya yang antara lain kelompok tumbuhan obat tradisional, kelompok getah, resin, kopal dan damar, tanaman hias, madu dan sumber bahan makanan (Maimunah S., 2015).

Dalam hal teknik pengelolaan hutan pendidikan, perlu adanya dukungan dan partisipasi aktif masyarakat sekitar kawasan hutan. Disisi lain dalam pengamanan kawasan hutan diperlukan peran aktif masyarakat sekitar kawasan hutan, sehingga keberadaan masyarakat di kawasan bukan menjadi ancaman atau gangguan pada kegiatan, terutama untuk peningkatan ekonomi masyarakat sekitar kawasan hutan. Diharapkan masyarakat kawasan hutan akan mendapat manfaat dari hutan secara langsung sehingga ada keinginan kuat untuk melindungi hutan karena memberi manfaat ekonomi bagi mereka.

Model perlindungan hutan untuk era reformasi menghendaki bentuk model yang lebih berbasis pada kemauan dan kehendak masyarakat secara positif, dimana masyarakat diminta pendapatnya dan dilibatkan dalam pengelolaan, sehingga masyarakat dijadikan subjek kegiatan.

\section{Metode}

Metode yang digunakan dalam penelitian ini adalah pendataan beberapa potensi HHBK yang berpeluang ekonomi dan peluang pasar untuk menopang kehidupan masyarakat sekitar kawasan hutan pendidikan dengan sistem Focus Group Discusion (FGD) dan data dari lapangan tentang potensi HHBK di hutan pendidikan untuk setiap tipe habitat.

\section{Hasil dan Pembahasan}

Model perlindungan dan pengelolaan hutan yang dianggap efektif di Hutan Pendidikan UM Palangkaraya setelah diamati latar belakang budaya dan mindset masyarakat adalah model pengelolaan secara kolaboratif dengan masyarakat dimana masyarakat selalu dalam pembinaan dan dilibatkan dalam kegiatan operasional di lapangan khususnya sebagai kelompok pengumpul produk HHBK unggulan di kawasan.

Masyarakat yang berlatar belakang sebagai petani, nelayan dan penambang yang cenderung dianggap illegal yang pada dasarnya adalah mereka hanya mencari 
kebutuhan pokoknya saja bisa dijadikan dasar untuk menghimpun mereka dan membentuk kelompok binaan tetap sebagai pengumpul getah yang bisa diberi beberapa seri pelatiihan yang intensif guna peningkatan kualitas kerja untuk menghasilkan damar sebanyak-banyaknya sesuai permintaan pasar. Model perlindungan ini dinilai efektif diterapkan di hutan pendidikan dengan menimbang kondisi sosial dan ekonomi masyrakat sekitar kawasan hutan adalah pemanfaatan HHBK.

Model yang ditawarkan dapat dilihat pada Bagan berikut :

\section{MODEL PENGELOLAAN/PERLINDUNGAN HUTAN PENDIDIKAN UM PALANGKARAYA KHUSUS HHBK}

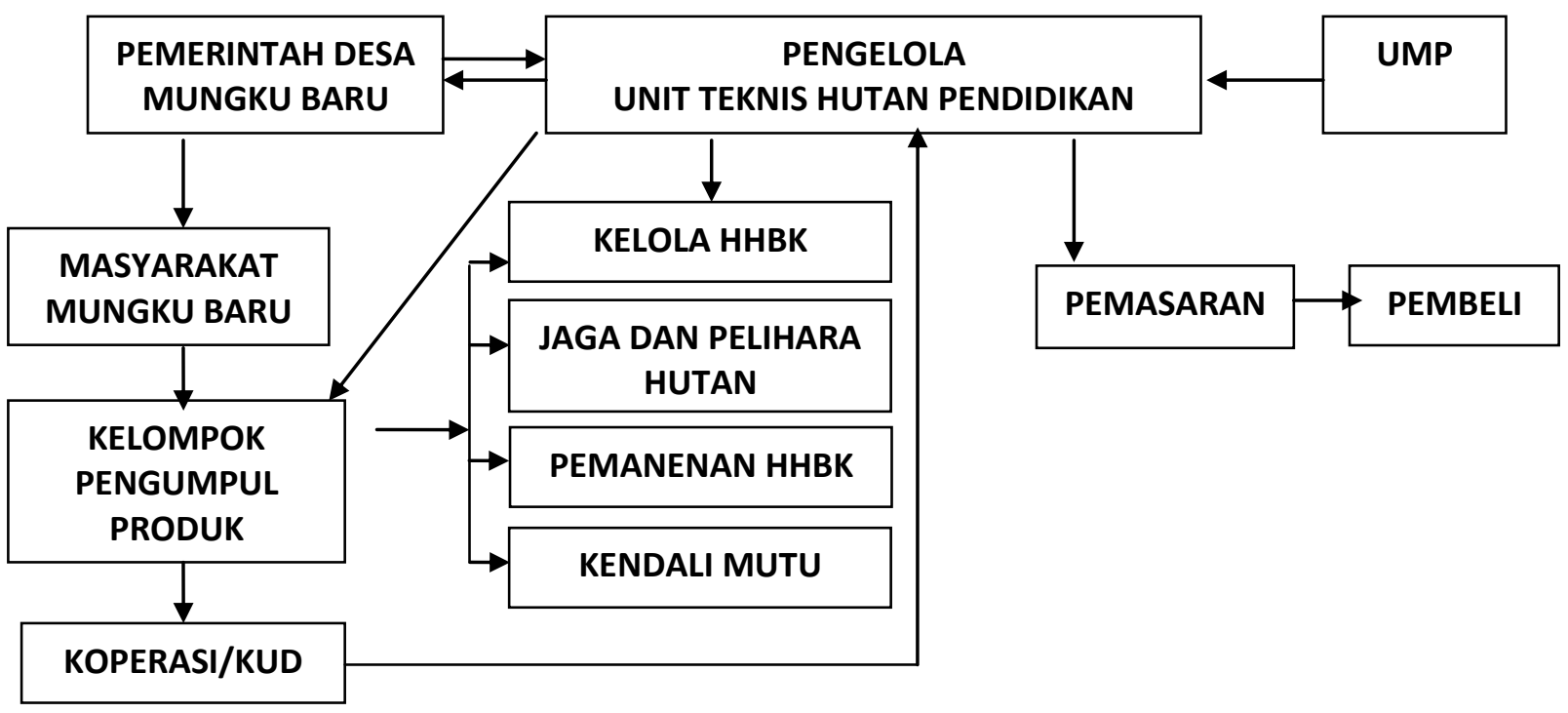

Bagan diatas menerangkan bahwa Pada unit HHBK ini masyarakat sistem pengelolaan Hutan Pendidikan Mungku Baru atas koordinasi antara Unit dilaksanakan secara terpadu, kolaborasi antara Universitas Muhammadiyah Palangkaraya selaku pengelola resmi menunjuk Tim Unit Teknis Hutan Pendidikan dengan tujuan pengelolaan hutan yang kompleks yang satu diantaranya adalah pengelolaan produk HHBK. Teknis Hutan Pendidikan dan kepala Desa/Lurah akan membentuk Kelompokkelompok masyarakat pengumpul HHBK untuk semua produk yang terpilih sesuai permintaan pasar. Kelompok-kelompok tersebut dihimpun dalam lembaga ekonomi desa dalam bentuk koperasi (KUD) untuk membantu menghubungkan Unit Teknis 
dalam pemasaran HHBK. Unit Teknis berkewajiban mencari pasar dan menjual produk secara berkelanjutan.

Kegiatan rutin yang dilaksanakan di desa / kelurahan adalah melakukan pemungutan dan pengelolaan hutan di kawasan hutan pendidikan sesuai produk yang diminta pasar dengan selalu menjaga dan mmelihara hutan agar terjaga dan aman. Kegiatan pengkayaan dan penangkaran beberapa jenis endemik terutam penghasil HHBK seperti tumbuhan obat tradisional dan tanaman hias selalu dilakukan secara kesinambungan untuk menjaga produksi yang berkelanjutan dengan tetap menjaga kualitas dan kuantitas produk. Unit teknis selalu mencari informasi permintaan pasar untuk produk HHBK unggulan yang bisa dipasarkan dengan selalu melaksanakan tugas secara bertanggungjawab.
Model tersebut diaplikasi di masyarakat dan dipahami serta disepakati untuk dilaksanakan. Persetujuan tidak menemui kendala karena masyarakat paham dan serius karena dilakukan untuk kepentingan ekonomi, dan kita mengajak masyarakat untuk mengelola ekonomi yang lestari yaitu dengan memungut HHBK dengan tidak merusak kawasan hutan maupun kondisi hutan yang ada. Tanpa sadar masyarakat secara langsung akan terlibat dalam patroli pengamanan hutan disamping memanen HHBK yang menguntungkan mereka.

Kegiatan diawali dengan menggali potensi kawasan dan permintaan pasar. Dari hasil penelitian sebelumnya diketahui bahwa kawasan Hutan pendidikan UM Palangkaraya mempunyai potensi ada sedikitnya 18 jenis produk HHBK unggulan seperti terlihat pada Tabel 1 berikut

TABEL 1 Potensi HHBK Hutan Pendidikan UM Palangkaraya

\begin{tabular}{|c|l|l|l|}
\hline No. & \multicolumn{1}{|c|}{ Produk KKBK } & No. & \multicolumn{1}{c|}{ Produk KKBK } \\
\hline 1 & damar batu & 10 & Sarang semut \\
\hline 2 & damar mata kucing & 11 & Anggrek \\
\hline 3 & kopal & 12 & kantong semar \\
\hline 4 & Nyatoh & 13 & Pasak bumi \\
\hline 5 & Gemor & 14 & Seluang Belum \\
\hline 6 & Jelutung & 15 & Sintok \\
\hline 7 & Kapur naga & 16 & Hewan buruan \\
\hline 8 & Madu & 17 & Jamur \\
\hline 9 & Rotan & 18 & Ikan \\
\hline
\end{tabular}


Dari data potensi tersebut, kemudian dijadikan dasar untuk menggali kemauan dan kemampuan masyarakat mengusahakan dan mengumpulkan HHBK. Kegiatan penggalian informasi tentang kehidupan sosial dan ekonomi masyarakat kawasan hutan pendidikan dilakukan dengan metode focus group discusion (FGD) sehingga bisa diketahui kemauan dan kemampuan masyarakat dan kegiatan ekonomi masyarakat yang ada di lokasi. Dalam kegiatan FGD tersebut dipaparkan tentang potensi HHBK yang memungkinkan di hutan pendidikan untuk diusahakan oleh masyarakat. Dari 18 jenis HHBK yang potensial di hutan pendidikan UM Palangkaraya ternyata damar batu mempunyai potensi terbesar dan termudah dalam pemungutannya sehingga terpilih untuk diusahakan oleh masyarakat untuk sementara waktu sesuai permintaan pasar.

Damar batu adalah resin dari jenis tanaman famili Dipterocarpaceae dari jenis Shorea spp (dari beberapa jenis genus Shorea) yang dapat digunakan untuk beberapa keperluan industri seperti korek api, sambungan kapal yang tahan air, obor, dupa, bahan pelapis, bahan pembuat plastik, plester, vernis, lak, cat, tinta, soda dan sebagainya bahkan sebagai bahan pengganti batu untuk perhiasan yang dikenal dengan batu damar (Baharudin dan Taskirawati, 2009). Pemasaran damar ini diekspor ke negara India dan Timur Tengah.

Pengumpulan dilakukan oleh Unit Teknis hutan pendidikan UM Palangkaraya untuk menjembatani masyarakat dengan pihak pembeli. Dari hasil pengumpulan damar batu diketahui bahwa masyarakat mempunyai kemampuan mengumpulkan damar batu $50 \mathrm{~kg} /$ hari/pengumpul dengan penghasilan rata-rata masyarakat pengumpul damar Rp. 125.000,00/hari/pengumpul damar.

Penghasilan ini jika rutin dilaksanakan akan sangat mengurangi aktivitas masyarakat untuk merusak hutan, karena ada di atas upah minimum rata-rata dan masyarakat bisa bergantung pada kegiatan ini untuk kebutuhan ekonominya. Grafik 1 berikut menggambarkan respon masyarakat untuk mengikuti saran pengelola hutan pendidikan untuk menjadi pengumpul damar batu yang dilakukan selama 4 bulan pertama yaitu sebagai berikut : 


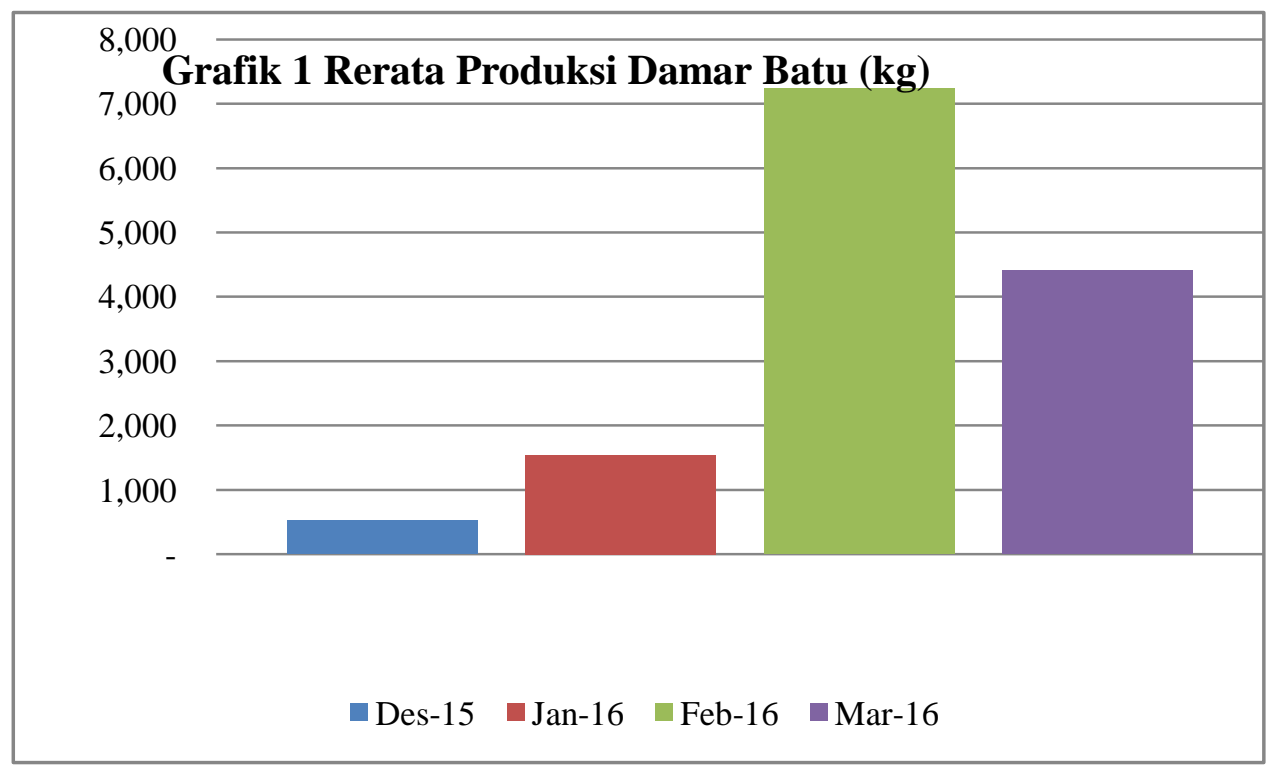

Penurunan produksi bukan disebabkan karena berkurangnya potensi damar yang ada, namun lebih pada penumpukan damar yang menunggu dipasarkan. Pemasaran dilakukan apabila telah memenuhi volume satu container sehingga mengalami penundaan pengiriman. Harga damar yang fluktuatif juga mengakibtkan adanya penumpukan produk untuk waktu yang relatif lama. Modal yang besar diperlukan untuk menutup keuangan untuk pembelian getah di masyarakat.
Jika dianalisa dari minat masyarakat untuk menjadi kelompok pengumpul getah/ damar, pada Grafik 2 terlihat terjadi penurunan juga pada bulan keempat karena pengarruh penumpukan produkuntuk menunggu pembeli dan permainan pasar namun penawaran selalu dilakukan untuk mendapatkan pembeli dibantu berbagai pihak. Tujuan kegiatan ini hanyalah bagaimana masyarakat beralih profesi dari pembuka ladang, penambang liar dan perusak lingkungan menjadi msyarakat yang konservatif.

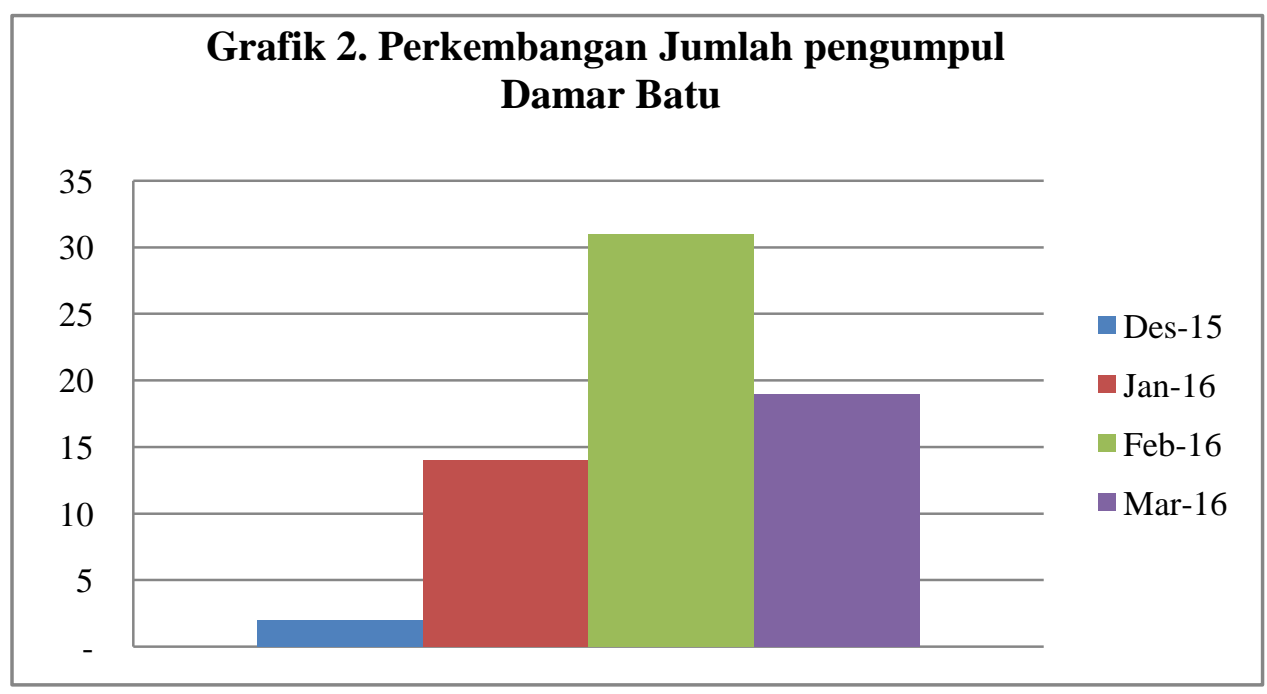


Disamping jumlah pengumpul yang menurun, prestasi kerja para pengumpul juga menurun seperti terlihat di Grafik 3 berikut. Jika dicari informasi penyebabnya karena lokasi mencari daar semakin hari semakin jauh sehingga mulai tidak semangat untuk mencarinya. Harga ditawar untuk naik lagi dari harga dasar, namun pihak unit teknis keberatan dengan harga yang ditawarkan masyarakat, menimbang harga pasaran damar yang fluktuatif.

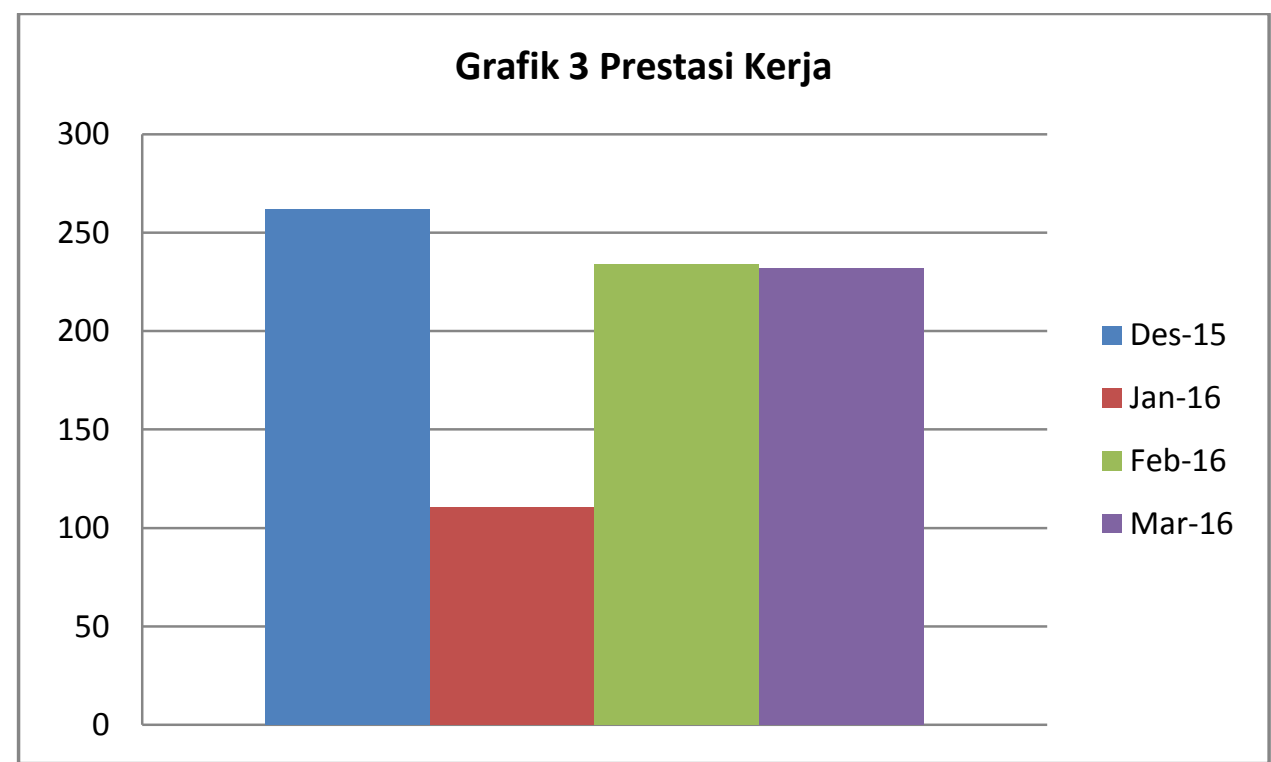

Dari kegiatan yang dilaksanakan, masyarakat belum optimal memanfaatkan hutan selain kayu dan cenderung melakukan penebangan liar hanya untuk membuat ladang berpindah. Masyarakat harus selalu didampingi dan diberi motivasi untuk selalu mengutamakan produk HHBK untuk menopang kehidupan ekonomi mereka. Meskipun informasi pengembangan HHBK di kawasan belum banyak diketahui masyarakat karena tidak adanya informasi pasar beberapa produk HHBK potensial kawasan Hutan Pendidikan namun inforasi selalu dicari guna memberi semangat kepada masyarakat dan memberi keyakinan yang teguh bahwa HHBK sebagai solusi paling tepat.

\section{Kesimpulan dan Saran}

\section{Kesimpulan :}

Hasil yang diperoleh bahwa model perlindungan hutan yang efektif diterapkan di hutan pendidikan adalah dengan melibatkan masyarakat kawasan hutan dalam kegiatan dalam model pengelolan/perlindungan hutan melalui HHBK yang dilakukan bersama 
masyarakat kawasan hutan pendidikan dengan beberapa kesimpulan, antara lain :

1. Masyarakat belum optimal memanfaatkan hutan selain kayu dan cenderung melakukan penebangan liar hanya untuk membuat ladang berpindahdan informasi pengembangan HHBK di kawasan belum banyak diketahui masyarakat karena tidak adanya informasi pasar beberapa produk HHBK potensial kawasan Hutan Pendidikan.

2. Produk HHBK unggulan kawasan tersebut antara lain dammar batu, kopal damar ,getah jelutung, rotan dan tumbuhan obat tradisional.

3. Produk unggulan tahun 20152016 adalah damar batu dengan hasil 50 $\mathrm{kg} /$ hari/pengumpul dengan penghasilan rata-rata masyarakat pengumpul damar Rp.

125.000,00/hari/pengumpul damar.

\section{Saran}

1. Perlu adanya pendampingan dan sosialisasi guna peningkatan keterlibatan masyarakat dalam pemanfaatan HHBK di kawasan tersebut.

2. Penguatan pembentukan lembaga koperasi

\section{Daftar Pustaka}

Baharudin dan Taskirawati, I., 2009. Hasil Hutan Bukan kayu. Fakultas Kehutanan Universitas Hassanudin Makassar.

Maimunah S., 2015. Laporan Resmi Tahunan Pengelolaan KHDTK Hutan Pendidikan UM Palangkaraya

Syamsu Alam, Supratman dan Alif, M., 2009. Ekonomi Sumber Daya Hutan. Laboratorium Kebijakan dan Kewirausahaan kehutanan. Fakultas Kehutanan Universitas Hassanudin Makassar. 